\title{
The Chinchilla Local Fauna: An exceptionally rich and well-preserved Pliocene vertebrate assemblage from fluviatile deposits of south-eastern Queensland, Australia
}

Julien Louys and Gilbert J. Price

Acta Palaeontologica Polonica 60 (3), 2015: 551-572 doi:http://dx.doi.org/10.4202/app.00042.2013

The Chinchilla Sand is a formally defined stratigraphic sequence of Pliocene fluviatile deposits that comprise interbedded clay, sand, and conglomerate located in the western Darling Downs, south-east Queensland, Australia. Vertebrate fossils from the deposits are referred to as the Chinchilla Local Fauna. Despite over a century and a half of collection and study, uncertainties concerning the taxa in the Chinchilla Local Fauna continue, largely from the absence of stratigraphically controlled excavations, lost or destroyed specimens, and poorly documented provenance data. Here we present a detailed and updated study of the vertebrate fauna from this site. The Pliocene vertebrate assemblage is represented by at least 63 taxa in 31 families. The Chinchilla Local Fauna is Australia's largest, richest and best preserved Pliocene vertebrate locality, and is eminently suited for palaeoecological and palaeoenvironmental investigations of the late Pliocene.

Key words: Mammalia, Marsupialia, Pliocene, Australia, Queensland, Darling Downs.

Julien Louys [julien.louys@anu.edu.au], Department of Archaeology and Natural History, School of Culture, History, and Languages, ANU College of Asia and the Pacific, The Australian National University, Canberra, 0200, Australia; Gilbert J. Price [g.price1@uq.edu.au], School of Earth Sciences, The University of Queensland, Brisbane, Queensland, 4072, Australia.

This is an open-access article distributed under the terms of the Creative Commons Attribution License (for details please see creativecommons.org), which permits unrestricted use, distribution, and reproduction in any medium, provided the original author and source are credited. 
Porif Full text $(1,124.0 \mathrm{kB})$ ।

FoF 5 Supplementary file $(103.8 \mathrm{kB})$ 